\title{
HISTOPATHOLOGICAL SPECTRUM OF ENDOMETRIAL LESIONS IN CASES OF ABNORMAL UTERINE BLEEDING AT A TERTIARY CARE HOSPITAL.
}

\footnotetext{
1. MBBS, FCPS (Histopathology) Assistant Professor Pathology Faisalabad Medical University, Faisalabad.

2. MBBS, DCP, M.Phil (Morbid Anatomy \& Histopathology), Associate Professor Pathology MMDC, Multan

3. MBBS

Demonstrator Pathology

MMDC, Multan.

4. MBBS, FRCS

Assistant Professor Surgery, HitechIMS. Taxila.

5. MBBS, FCPS (Chemical Pathology) Assistant Professor Pathology MMDC, Multan

6. MBBS, DCP Associate Professor Pathology MMDC, Multan.
}

Correspondence Address:

Dr. Namra Naeem

Pathology

Faisalabad Medical University,

Faisalabad.

namran88@gmail.com

Article received on:

29/01/2020

Accepted for publication:

05/03/2020

\begin{abstract}
Namra Naeem ${ }^{1}$, Afra Samad ${ }^{2}$, Safia Sartaj ${ }^{3}$, Muhammad Farooq ${ }^{4}$, Nudrat Fayyaz ${ }^{5}$, Muhammad Naeem Choudhary ${ }^{6}$

ABSTRACT... Objectives: To assess histological spectrum of endometrial lesions in abnormal uterine bleeding at a tertiary care hospital. Study Design: Cross Sectional study. Setting: Department of Pathology, Multan Medical \& Dental College, Multan and Faisalabad Medical University, Faisalabad. Period: January, 2019 to December, 2019. Material \& Methods: Using non - probability purposive sampling technique. Results: A total of 238 ladies presenting with abnormal uterine bleeding were registered in our study. Mean age of these patients with AUB was $47.25 \pm 5.57$ years (ranging 21 years to 59 years), $158(66.4 \%)$ were aged more than 45 years. Eighty five (35.7\%) were from rural areas while $153(64.3 \%)$ from urban areas. Of these 238 females, $162(68.1 \%)$ were illiterate and $76(31.9 \%)$ were literate. Majority of patients i.e. $218(91.6 \%)$ were married and mean duration of illness was $5.28 \pm 3.89$ months while $169(71 \%)$ presented within 6 months of illness. Histopathological pattern revealed Proliferative phase endometrium was observed in 69 (29\%), endometrial hyperplasia in 59 (24.8\%), chronic endometritis in 40 (16.8\%), secretory phase in 40 (16.8\%), atrophic endometrium in 30 (12.6\%) and endometrial polyps in 10 (4.2\%). Conclusion: Histological pattern revealed proliferative endometrium was commonest followed by hyperplasia, secretory phase and chronic endometritis in our study. Disordered proliferative endometrium was commonly observed in married females and those having duration of symptoms more than 6 months. Hyperplasia was more frequent in older patients who were married. Secretory phase was significantly more common in patients with prolonged disease and chronic endometritis was associated with marital status and prolonged disease duration.
\end{abstract}

Key words: $\quad$ Abnormal Uterine Bleeding, Endometrium, Histopathological Pattern.

Article Citation: Naeem N, Samad A, Sartaj S, Farooq M, Fayyaz N, Choudhary. Histopathological spectrum of endometrial lesions in cases of abnormal uterine bleeding at a Tertiary Care Hospital. Professional Med J 2020; 27(8):1692-1696. DOI: 10.29309/TPMJ/2020.27.08.4533

\section{INTRODUCTION}

Abnormal uterine bleeding (AUB) is one of the most common gynecological complaints which accounts for estimated $30 \%$ of outpatient visits to gynecologists. ${ }^{1-3}$ Abnormal bleeding can be due to various local and underlying systemic illness or associated with wide variety of medications. Commonest etiologies of AUB in non-pregnant ladies include uterine pathology (e.g. fibroids, adenomyosis and endometrial polyps), neoplasia, anovulation and hemostasis disorders. ${ }^{1}$ AUB is significant healthcare burden in suffering women which has negative effect on quality of life, healthcare services, loss of productivity and selfesteem. ${ }^{4,5}$
Endometrium is a dynamic tissue which undergoes cyclic changes including a proliferative phase, ovulation, secretory phase, predecidual changes, breakdown of stroma and ultimately casting off of superficial layer of endometrium during menstruation. ${ }^{6}$ Clinically, abnormal uterine bleeding may be defined as variations in frequency, amount and duration from normal pattern of menstrual cycles. It also includes postmenopausal bleeding. ${ }^{7}$ History, physical examination and laboratory investigations may not be sufficient to reach a definitive diagnosis of abnormal uterine bleeding and it is often necessary to sample endometrium for histopathological analysis. There are a variety of ways to sample endometrium, but endometrial curettage is the 
method of choice. Very few, if any lesions can escape detection by endometrial curettage. It has sensitivity greater than endometrial biopsy. ${ }^{8-10}$

Histological spectrum of endometrial lesions is greatly influenced by the age of the patient. In older age group,(particularly after menopause) endometrial hyperplasias and endometrial carcinomas are more prevalent, whereas dysfunctional uterine bleeding is more common in younger age group. ${ }^{11}$ A study carried out in Pakistan in 2011 for evaluating the spectrum of endometrial lesions in abnormal uterine bleeding found endometrial lesions in order of following frequencies: hormonal imbalances(41\%), endometrial polyp (21\%), and chronic endometritis (18\%). ${ }^{12}$ Another study in Nepal reported secretory phase to be $22.58 \%$ and disordered proliferative to be $13.40 \%{ }^{7} \mathrm{~A}$ similar study in India which included 119 patients found that proliferative endometrium accounted for $35.22 \%$ and endometrial hyperplasia for $23.86 \%$ in perimenopausal age group whereas atrophic endometrium accounted for $25.80 \%$ and endometrial hyperplasia for $19.35 \%$ in postmenopausal age group. ${ }^{13}$

The rationale of this study is to evaluate the histological patterns of endometrium in patients with abnormal uterine bleeding in Southern Punjab. This data will enable us to know health literacy and design various screening programmes. In addition, this data will guide gynaecologist to modify their treatment strategies.

\section{MATERIAL \& METHODS}

A total of 238 ladies aged less than 60 years presenting with abnormal uterine bleeding (having menstrual cycle duration less than 21 days or more than 35 days or a menstrual flow of less than 2 days or more than 7 days for more than 3 months) were recruited in this cross sectional study which was conducted at Department of Pathology, Multan Medical \& Dental College, Multan and Faisalabad Medical University, Faisalabad from January 2019 to December 2019. Pregnant ladies, having bleeding disorders and having cardiovascular diseases were excluded from our study. Clinical specimens (endometrial curettage) of these patients were taken after fixation in 10\% formalin buffer, grossed and then staining was done with hematoxylin and Eosin to diagnose their morphological characteristics and noted on study proforma.

Data entry was done using SPSS version 23, mean and standard deviation were calculated. Other categorical variables like marital status, age groups, residential status and histopathological characteristics were analyzed in terms of frequencies and percentages. Stratification of data was also done to control risk of confounders by applying Pearson Chi - square test at $95 \% \mathrm{Cl}$.

\section{RESULTS}

A total of 238 ladies presenting with abnormal uterine bleeding were registered in our study. Mean age of these patients with AUB was 47.25 \pm 5.57 years (ranging 21 years to 59 years), 158 (66.4\%) were aged more than 45 years. Eighty five $(35.7 \%)$ were from rural areas while 153 $(64.3 \%)$ from urban areas. Of these 238 females, $162(68.1 \%)$ were illiterate and $76(31.9 \%)$ were literate. Majority of patients i.e. 218 (91.6\%) were married and mean duration of illness was $5.28 \pm$ 3.89 months while 169 (71\%) presented within 6 months of illness. Histopathological pattern revealed Proliferative phase endometrium was observed in 69 (29\%), endometrial hyperplasia in 59 (24.8\%), chronic endometritis in 40 $(16.8 \%)$, secretory phase in 40 (16.8\%), atrophic endometrium in 30 (12.6\%) and endometrial polyps in 10 (4.2\%).

\begin{tabular}{|c|c|c|c|c|}
\hline \multirow{2}{*}{\multicolumn{2}{|c|}{ Effect Modifiers }} & \multicolumn{2}{|c|}{$\begin{array}{c}\text { Proliferative } \\
\text { Phase }\end{array}$} & \multirow{2}{*}{$\begin{array}{c}\text { P- } \\
\text { Value }\end{array}$} \\
\hline & & Yes & No & \\
\hline \multirow{2}{*}{$\begin{array}{l}\text { Age groups } \\
\text { (In Years) }\end{array}$} & Up to $45(n=80)$ & 20 & 60 & \multirow{2}{*}{0.367} \\
\hline & More than $45(n=158)$ & 49 & 109 & \\
\hline \multirow{2}{*}{$\begin{array}{l}\text { Residential } \\
\text { status }\end{array}$} & Rural $(n=85)$ & 24 & 61 & \multirow{2}{*}{0.882} \\
\hline & Urban $(n=153)$ & 45 & 108 & \\
\hline \multirow{2}{*}{ Literacy } & Illiterate $(n=162)$ & 50 & 112 & \multirow{2}{*}{0.444} \\
\hline & Literate $(n=76)$ & 19 & 57 & \\
\hline \multirow{2}{*}{$\begin{array}{l}\text { Marital } \\
\text { Status }\end{array}$} & Married $(n=218)$ & 69 & 149 & \multirow{2}{*}{0.002} \\
\hline & Un-married $(n=20)$ & 00 & 20 & \\
\hline \multirow{2}{*}{$\begin{array}{l}\text { Disease } \\
\text { duration }\end{array}$} & Up to 6 months $(n=169)$ & 59 & 110 & \multirow[b]{2}{*}{0.003} \\
\hline & $\begin{array}{l}\text { More than } 6 \text { months } \\
(n=69)\end{array}$ & 10 & 59 & \\
\hline \multicolumn{5}{|c|}{$\begin{array}{l}\text { Table-I. Stratification of proliferative phase } \\
\text { endometrium with regards to different effect } \\
\text { modifiers }(n=150)\end{array}$} \\
\hline
\end{tabular}




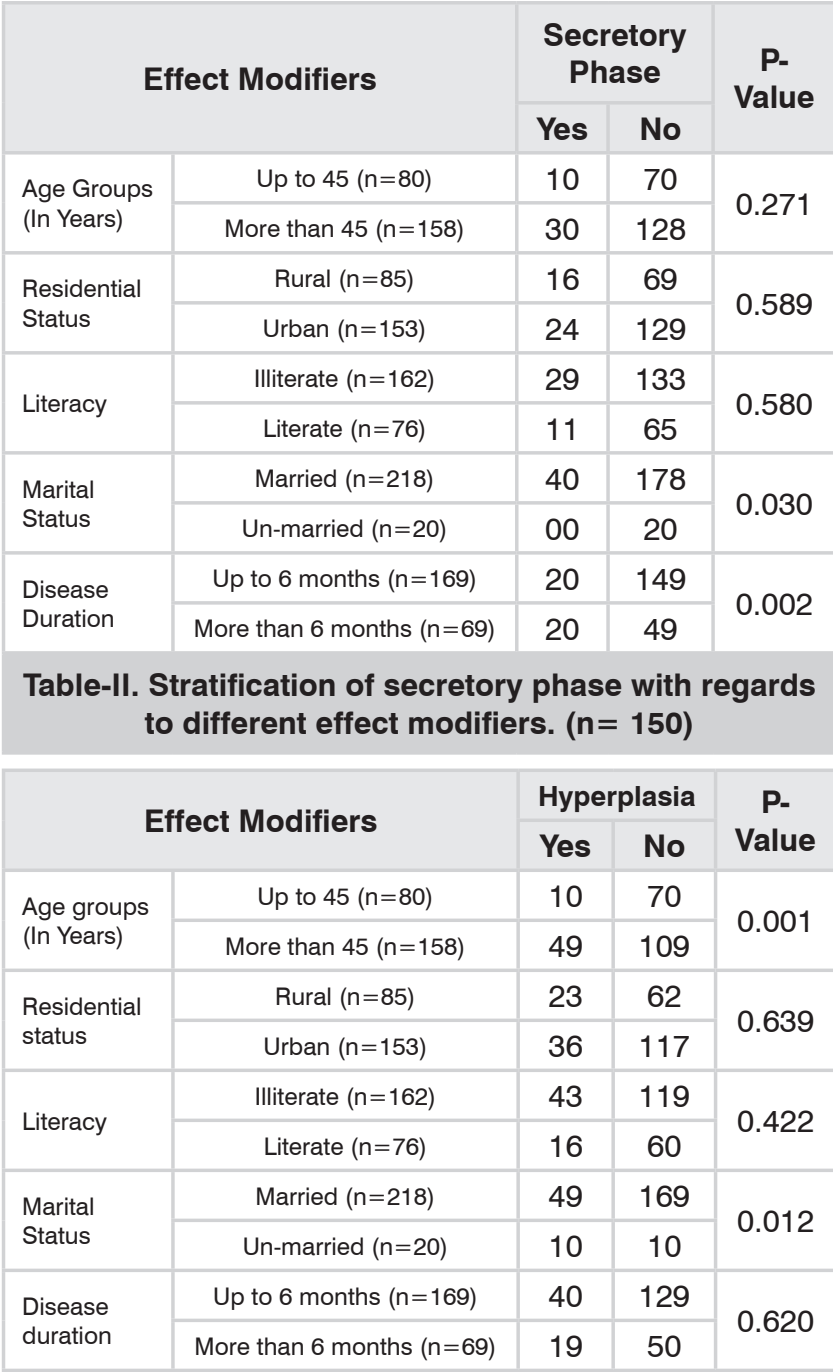

Table-III. Stratification of hyperplasia with regards to different effect modifiers. $(n=150)$

\begin{tabular}{|c|c|c|c|c|}
\hline \multicolumn{2}{|c|}{ Effect Modifiers } & \multicolumn{2}{|c|}{$\begin{array}{c}\text { Atrophic } \\
\text { Phase }\end{array}$} & \multirow{2}{*}{$\begin{array}{c}\text { P. } \\
\text { Value }\end{array}$} \\
\hline & & Yes & No & \\
\hline \multirow{2}{*}{$\begin{array}{l}\text { Age groups } \\
\text { (In Years) }\end{array}$} & Up to $45(n=80)$ & 20 & 60 & \multirow{2}{*}{0.001} \\
\hline & More than $45(n=158)$ & 10 & 148 & \\
\hline \multirow{2}{*}{$\begin{array}{l}\text { Residential } \\
\text { status }\end{array}$} & Rural $(n=85)$ & 08 & 77 & \multirow{2}{*}{0.313} \\
\hline & Urban $(n=153)$ & 22 & 131 & \\
\hline \multirow{2}{*}{ Literacy } & Illiterate $(n=162)$ & 15 & 147 & \multirow{2}{*}{0.035} \\
\hline & Literate $(n=76)$ & 15 & 61 & \\
\hline \multirow{2}{*}{$\begin{array}{l}\text { Marital } \\
\text { Status }\end{array}$} & Married $(n=218)$ & 30 & 188 & \multirow{2}{*}{0.086} \\
\hline & Un-married $(n=20)$ & 00 & 20 & \\
\hline \multirow{2}{*}{$\begin{array}{l}\text { Disease } \\
\text { duration }\end{array}$} & Up to 6 months $(n=169)$ & 30 & 139 & \multirow{2}{*}{0.001} \\
\hline & More than 6 months $(n=69)$ & 00 & 69 & \\
\hline
\end{tabular}

Table-IV. Stratification of atrophic endometrium with regards to different effect modifiers. $(n=150)$

\begin{tabular}{|c|c|c|c|c|}
\hline \multirow{2}{*}{\multicolumn{2}{|c|}{ Effect Modifiers }} & \multicolumn{2}{|c|}{$\begin{array}{l}\text { Chronic } \\
\text { Endometritis }\end{array}$} & \multirow{3}{*}{$\begin{array}{c}\begin{array}{c}\text { P- } \\
\text { Value }\end{array} \\
0.271\end{array}$} \\
\hline & & Yes & No & \\
\hline \multirow{2}{*}{$\begin{array}{l}\text { Age groups } \\
\text { (In Years) }\end{array}$} & Up to $45(n=80)$ & 10 & 70 & \\
\hline & More than $45(n=158)$ & 30 & 128 & \\
\hline \multirow{2}{*}{$\begin{array}{l}\text { Residential } \\
\text { status }\end{array}$} & Rural $(n=85)$ & 15 & 70 & \multirow{2}{*}{0.857} \\
\hline & Urban $(n=153)$ & 25 & 128 & \\
\hline \multirow{2}{*}{ Literacy } & Illiterate $(n=162)$ & 29 & 133 & \multirow{2}{*}{0.580} \\
\hline & Literate $(\mathrm{n}=76)$ & 11 & 65 & \\
\hline \multirow{2}{*}{$\begin{array}{l}\text { Marital } \\
\text { Status }\end{array}$} & Married $(n=218)$ & 40 & 178 & \multirow{2}{*}{0.030} \\
\hline & Un-married $(n=20)$ & 00 & 20 & \\
\hline \multirow{2}{*}{$\begin{array}{l}\text { Disease } \\
\text { duration }\end{array}$} & Up to 6 months $(n=169)$ & 21 & 148 & \multirow[b]{2}{*}{0.003} \\
\hline & $\begin{array}{l}\text { More than } 6 \text { months } \\
\qquad(\mathrm{n}=69)\end{array}$ & 19 & 50 & \\
\hline
\end{tabular}

Table-V. Stratification of Chronic endometritis with regards to different effect modifiers. $(n=150)$

\begin{tabular}{|c|c|c|c|c|}
\hline \multicolumn{2}{|c|}{ Effect Modifiers } & \multicolumn{2}{|c|}{$\begin{array}{l}\text { Endometrial } \\
\text { Polyps }\end{array}$} & \multirow{4}{*}{$\begin{array}{c}\text { P. } \\
\text { Value } \\
0.001\end{array}$} \\
\hline & & Yes & No & \\
\hline \multirow{2}{*}{$\begin{array}{l}\text { Age groups } \\
\text { (In Years) }\end{array}$} & Up to $45(n=80)$ & 10 & 70 & \\
\hline & More than $45(n=158)$ & 00 & 158 & \\
\hline \multirow{2}{*}{$\begin{array}{l}\text { Residential } \\
\text { status }\end{array}$} & Rural $(n=85)$ & 03 & 82 & \multirow{2}{*}{1.000} \\
\hline & Urban $(n=153)$ & 07 & 146 & \\
\hline \multirow{2}{*}{ Literacy } & Illiterate $(n=162)$ & 05 & 157 & \multirow{2}{*}{0.297} \\
\hline & Literate $(n=76)$ & 05 & 71 & \\
\hline \multirow{2}{*}{$\begin{array}{l}\text { Marital } \\
\text { Status }\end{array}$} & Married $(n=218)$ & 00 & 218 & \multirow{2}{*}{0.001} \\
\hline & Un-married $(n=20)$ & 10 & 10 & \\
\hline \multirow{2}{*}{$\begin{array}{l}\text { Disease } \\
\text { duration }\end{array}$} & $\begin{array}{l}\text { Up to } 6 \text { months } \\
(n=169)\end{array}$ & 10 & 159 & \multirow{2}{*}{0.067} \\
\hline & $\begin{array}{l}\text { More than } 6 \text { months } \\
\qquad(n=69)\end{array}$ & 00 & 69 & \\
\hline \multicolumn{5}{|c|}{$\begin{array}{l}\text { Table-VI. Stratification of endometrial polyps with } \\
\text { regards to different effect modifiers. }(n=150)\end{array}$} \\
\hline
\end{tabular}

\section{DISCUSSION}

Spectrum of commonly encountered pathologies which are diagnosed in AUB histologically may include hormonal imbalance pattern such as "disordered proliferative endometrium, non secretory endometrium with stromal and glandular breakdown, luteal phase defect and pill effect", endometrial hyperplasia, endometrial polyps, atrophic endometrium, endometritis and endometrial carcinoma. ${ }^{14}$

A total of 238 ladies presenting with abnormal uterine bleeding were registered in our study. Mean age of these patients with AUB was 47.25 
\pm 5.57 years (ranging 21 years to 59 years), 158 (66.4\%) were aged more than 45 years. A study conducted by Abid et $\mathrm{al}^{12}$ in Karachi reported $40.3 \pm 11.06$ years mean age of the patients with abnormal uterine bleeding. Sajitha et $\mathrm{al}^{15}$ from India also reported majority of patients abnormal uterine bleeding were from age group of 46 - 60 years. Vaidya et $\mathrm{al}^{7}$ from Nepal also reported that majority of patients with abnormal uterine bleeding were from reproductive and perimenopausal age groups. Salvi et $\mathrm{al}^{16}$ from India reported $45.8 \pm 1.53$ years mean age of the patients with abnormal uterine bleeding. Ghani et $\mathrm{al}^{17}$ from Iraq and Bolde et $\mathrm{al}^{18}$ \& Singh et $\mathrm{al}^{19}$ from India have reported similar results.

Eighty five (35.7\%) were from rural areas while 153 (64.3\%) from urban areas. Of these 238 females, $162(68.1 \%)$ were illiterate and $76(31.9 \%)$ were literate. Majority of patients i.e. 218 (91.6\%) were married and mean duration of illness was $5.28 \pm$ 3.89 months while 169 (71\%) presented within 6 months of illness. Abid et al ${ }^{12}$ reported $73 \%$ ladies with abnormal uterine bleeding were married which is quite lower than being reported in our study.

Histopathological pattern revealed Proliferative phase endometrium was observed in 69 (29\%), endometrial hyperplasia in 59 (24.8\%), chronic endometritis in 40 (16.8\%), secretory phase in $40(16.8 \%)$, atrophic endometrium in $30(12.6 \%)$ and endometrial polyps in 10 (4.2\%). Abid et al ${ }^{12}$ reported endometrial polyps in $14 \%$, chronic endometritis in $12 \%$, atrophic endometrium 6\%, endometrial hyperplasia in $5 \%$ and endometrial carcinoma was $2 \%$. These findings of Abid et al ${ }^{12}$ are similar to that of our study results. Another study in Nepal reported secretory phase to be $22.58 \%$ and disordered proliferative to be $13.40 \% .^{7}$ A similar study in India which included 119 patients found that proliferative endometrium accounted for $35.22 \%$ and endometrial hyperplasia for $23.86 \%$ in perimenopausal age group whereas atrophic endometrium accounted for $25.80 \%$ and endometrial hyperplasia for $19.35 \%$ in postmenopausal age group. ${ }^{13}$ These results are in compliance with that of our study results. Salvi et $\mathrm{al}^{16}$ also reported from India proliferative endometrium being predominant histopathological diagnosis in these patients which is same as that of our study findings. Ghani et $\mathrm{al}^{17}$ from Iraq and Bolde et $\mathrm{al}^{18}$ \& Singh et $\mathrm{al}^{19}$ from India have also reported proliferative endometrium being more common histopahtological finding which is in compliance with that of our study results.

\section{CONCLUSION}

Histological pattern revealed proliferative endometrium was commonest followed by hyperplasia, secretory phase and chronic endometritis in our study. Disordered proliferative endometrium was commonly observed in married females and those having duration of symptoms more than 6 months. Hyperplasia was more frequent in older patients who were married. Secretory phase was significantly more common in patients with prolonged disease and chronic endometritis was associated with marital status and prolonged disease duration.

\section{CONFLICTS OF INTEREST}

It is declared that there was no potential conflict of interest relevant to this article.

\section{Copyright $@ 05$ Mar, 2020.}

\section{REFERENCES}

1. Committee on Practice Bulletins-Gynecology. Practice bulletin no. 128: Diagnosis of abnormal uterine bleeding in reproductive-aged women. Obstet Gynecol 2012; 120:197-206.

2. Matteson KA, Abed H, Wheeler TL, 2nd, Sung VW, Rahn DD, Schaffer Jl, et al. A systematic review comparing hysterectomy with less-invasive treatments for abnormal uterine bleeding. J Minim Invasive Gynecol. 2012; 19(1):13-28.

3. Singh S, Best C, Dunn S, Leyland N, Wolfman WL, Clinical Practice-Gynaecology Committee et al. Abnormal uterine bleeding in premenopausal women. J Obstet Gynaecol Can. 2013; 35(5):473-9.

4. Madhra $\mathrm{M}^{1}$, Fraser IS, Munro MG, Critchley $\mathrm{HO}$. Abnormal uterine bleeding: Advantages of formal classification to patients, clinicians and researchers. Acta Obstet Gynecol Scand. 2014 Jul; 93(7):619-25.

5. Whitaker $\mathrm{L}^{1}$, Critchley $\mathrm{HO}^{2}$. Abnormal uterine bleeding. Best Pract Res Clin Obstet Gynaecol. 2016 Jul; 34:5465. 
6. Rosai J. Rosai and Ackerman's Surgical Pathology. $10^{\text {th }}$ ed. St. Louis: Mosby an imprint of Elsevier; 2012. P.1477-79.

7. Vaidya S, Lakhey M, Vaidya SA, Sharma PK, Hirachand S, Lama S, et al. Histopathological pattern of abnormal uterine bleeding in endometrial biopsies. Nepal Med Coll J. 2013; 15(1):74-77.

8. Jetley S, Rana S, Jairajpuri ZS. Morphological spectrum of endometrial pathology in middle- aged women with atypical bleeding: A study of 219 Cases. J Midlife Health. 2013; 4(4):216-20.

9. Saraswathi D, Thanka J, Shakinee R, Aarthi R, Jaya V, Kumar PV, et al. Study of endometrial pathology in abnormal uterine bleeding. J Obstet Gynaecol India. 2011; $61(4): 426-30$.

10. Elleson LH, Pirog EC. The female genital tract. In: Kumar V, Abbas AK, Aster JC. Robbins and cotran pathological basis of disease. $9^{\text {th }}$ ed. Philadelphia, PA: Saunders Elsevier, 2014. p.1008-10.

11. Forae GD, Aligbe JU. Histopathological pattern of endometrial lesions in patients with abnormal uterine bleeding in a cosmopolitan population. J Basic Clin Reprod Sci. 2013; 2(2):101-04.

12. Abid M, Hashmi AA, Malik B, Haroon S, Faridi N, Edhi MM, et al. Clinical pattern and spectrum of endometrial pathologies in patients with abnormal uterine bleeding in Pakistan: Need to adopt a more conservative approach to treatment. BMC Womens Health. 2014; 14:132.
13. Damle RP, Dravid NV, Suryawanshi KH, Gadre AS, Bagale PS, Ahire N. Clinicopathological spectrum of endometrial changes in perimenopausal and postmenopausal abnormal uterine bleeding; a 2 year study. J Clin Diagn Res. 2013; 7(12):2774-76.

14. Glasser $\mathrm{MH}$. Commentary on 'Ten-year follow-up of a randomized controlled trial comparing bipolar endometrial ablation with balloon ablation for menorrhagia' BJOG. 2013; 120:970.

15. Sajitha K, Padma SK, Shetty K J, KishanPrasad H L, Permi HS, Hegde P. Study of histopathological patterns of endometrium in abnormal uterine bleeding. CHRISMED J Health Res 2014; 1:76-81.

16. Salvi A, Mital P, Hooja N, Batar A, Soni P, Beniwal R. Spectrum of endometrial histopathology in women presenting with abnormal uterine bleeding. Scholars J Applied Med Sci. 2015; 3(1):1-4.

17. Ghani NA, Abdulrazak AA, Abdullah EM. Abnormal uterine bleeding: A histopathological study. Diyala J Med. 2013; 4(1):55-60.

18. Bolde SA, Pudale SS, Pandit GA, Matkari PP. Histopathological study of endometrium in cases of abnormal uterine bleeding. Int J Res Med Sci. 2014; 2(4):1378-81.

19. Singh S, Pandey P, Agarwal S, Swarn K, Singh S. Spectrum of uterine lesions presenting as abnormal uterine bleeding in a rural north Indian population: A study from tertiary care center. Int J Res Med Sci. 2016; 4(8):3250-54.

\begin{tabular}{|l|l|l|}
\hline \multicolumn{3}{|c}{ AUTHORSHIP AND CONTRIBUTION DECLARATION } \\
\hline Sr. \# & \multicolumn{1}{|c|}{ Author(s) Full Name } & \multicolumn{1}{|c|}{ Contribution to the paper } \\
\hline 1 & Namra Naeem & Study design and data. \\
2 & Afra Samad & $\begin{array}{l}\text { Data collection and article } \\
\text { format. } \\
\text { Statistical analysis. }\end{array}$ \\
\hline 3 & Safia Sartaj & Technical support. \\
\hline 5 & Nudrat Fayyaz & Proof reading and final drafting. \\
\hline 6 & M. Naeem Choudhary & Expert and technical support. \\
\hline
\end{tabular}

